\title{
Morphological analysis of soil particles at multiple length-scale reveals nutrient stocks of Amazonian Anthrosols
}

\author{
Naiara C. Oliveira $^{\mathrm{a}}$, Alexandre R. Paschoal ${ }^{\mathrm{b}}$, Ricardo J. Paula ${ }^{\mathrm{a}}$, Isabela C. Constantino ${ }^{\mathrm{c}}$, \\ Marcia C. Bisinoti $^{\mathrm{c}}$, Altair B. Moreira ${ }^{\mathrm{c}}$, Lais G. Fregolente ${ }^{\mathrm{c}}$, Ariane M. Santana ${ }^{\mathrm{c}}$, \\ Francisco A. Sousa ${ }^{a, d}$, Odair P. Ferreira ${ }^{\mathrm{e}, *}$, Amauri J. Paula ${ }^{\mathrm{a}, *}$ \\ ${ }^{a}$ Solid-Biological Interface Group (SolBIN), Departamento de Física, Universidade Federal do Ceará, P.O. Box 6030, 60455-900 Fortaleza, CE, Brazil \\ b Laboratório de Espectroscopia Vibracional e Microscopia (LEVM), Departamento de Física, Universidade Federal do Ceará, P.O. Box 6030, 60455-900 Fortaleza, CE, \\ Brazil \\ ${ }^{c}$ Laboratório de Estudos em Ciências Ambientais, Instituto de Biociências, Letras e Ciências Exatas, UNESP, Univ Estadual Paulista, Campus São José do Rio Preto, \\ Departamento de Química e Ciências Ambientais, 15054-000 São José do Rio Preto, SP, Brazil \\ ' Instituto Federal do Rio Grande do Norte Campus Apodi, Apodi, RN, Brazil \\ e Laboratório de Materiais Funcionais Avançados (LaMFA), Departamento de Física, Universidade Federal do Ceará, P.O. Box 6030, 60455-900 Fortaleza, Ceará, Brazil
}

\section{A R T I C L E I N F O}

Handling Editor: Junhong Bai

Keywords:

X-ray energy dispersive spectroscopy

Sustained fertility

Carbon sequestration

Soil amendments

Terra Preta de Índio

Terra Mulata de Índio

\begin{abstract}
A B S T R A C T
We have imaged the particles of Brazilian soils at multiple length scales, from a few microns to millimeters, and soil particle size distributions were calculated with unmatched precision. The analysis included the Amazonian soil "Terra Mulata de Índio" (TMI), an anthropogenic soil (Anthrosol) with sustained fertility and a large amount of stabilized organic matter. Firstly, the soils were imaged ex situ, without any chemical processing, with sequential electron scanning of the pelletized soil samples, covering a total area of $8 \times 8 \mathrm{~mm}$. Secondly, it was performed a computational analysis of the large-field X-ray images assembled from hundreds of adjacent elemental maps, thus resulting in high-definition images $(4800 \times 4800$ pixels). This analytical approach provides a large sampling with the identification of $>10,000$ particles over the scanned area. The particles identified consisted of Al, C, Ca, Cr, F, Fe, Mg, Mn, Na, O, P, S, Si and Ti. A significantly larger concentration of C-, Ca- and P-based particles, of up to $100 \mu^{2}$ of cross-section area, was found in TMI samples in comparison with oxisol and ultisol soils. While the mean distance between neighboring C, Ca and P particles in TMI was of $40-70 \mu \mathrm{m}$, the value was of hundreds of microns in oxisol and ultisol. Furthermore, mapping of micrometric carbon particles by Raman spectroscopy indicated that they have a graphitic structure with a large amount of defects, partially associated with particle oxidation, although a well-preserved $\mathrm{sp}^{2}$ graphitic structure is also present. From a technological perspective, improved soil amendments, such as biochar, can be rationally designed from the "fingerprint" described here for soil particles of Amazonian Anthrosols (i.e., morphological and structural characteristics), which can result in an increase in fertility and the optimization of carbon sequestration in the future.
\end{abstract}

\section{Introduction}

The structure of soil is comprised of a hierarchical organization of inorganic and organic matter in levels, that range from the sub-nanometer to the macroscopic scale (Gimknez et al., 1997; Jastrow, 1996). Inorganic matter (i.e., minerals) is present in the ionized state and/or organized in clusters and particles (nano to macroscale) (Hughes et al., 1994; Kahle et al., 2002). On the other hand, organic matter includes all carbon-based molecules, molecular-assemblies and particles, including plant and animal residues, and the biomass of living microorganisms and other fauna (Lal, 2007; Rinnan and Rinnan, 2007). Fertility is manifested from the fine-tuning of the abovementioned compositional and structural aspects, and represents a complex and emergent property of soil (Chaparro et al., 2012). Consequently, soil fertility is a crucial aspect in crop yields and food security.

More specifically, the definition of soil fertility is related to its capacity for providing the needs for the growth and development of plants, including aspects of productivity, reproduction and the quality of the resulting crops (Abbott and Murphy, 2007; Atkinson et al., 2010). A modern and complete determination of soil fertility involves the

\footnotetext{
* Corresponding authors.

E-mail addresses: opferreira@fisica.ufc.br (O.P. Ferreira), amaurijp@fisica.ufc.br (A.J. Paula).
} 
assessment of biological, chemical and physical aspects, and the consequent multiple and complex interactions/relations between these three aspects. For the physico-chemical characterization of soils, there are well-established protocols for the identification and quantification of soil ions and molecules by analytical chemistry protocols, such as extraction and fractionation (Huo et al., 1998; Qian et al., 1996; Wang et al., 2017; Xinde et al., 2000); chromatographic and spectroscopic methods (Hernandez-Soriano et al., 2016; Jáuregui et al., 1998; Malley et al., 1999; Pascaud et al., 2017; Udelhoven et al., 2003). However, both the particle (inorganic and organic) fractions present in the soil are difficult to identify, classify and characterize in soil samples, especially ex situ, without sample preparation/processing. The largely used granulometric methods involving gradual sieving provide some insights into soil particle sizes (De Souza et al., 2016; Li et al., 2016; van Reeuwijk, 2002; Villaverde et al., 2009; Yin et al., 2016), but they do not allow for the measurement of precise particle size distribution (PSD) functions for soil particles. A precise determination of PSDs is of particular importance for feeding mathematical models of flow and transport processes that occur in soil, thus allowing the determination of soil water retention and other hydraulic properties (Arya and Paris, 1981; Gupta and Larson, 1979; Mohammadi and Vanclooster, 2014).

Alternatively, light-scattering (LS) techniques of soil dispersion in liquid media can essentially determine PSDs (e.g., dynamic LS). Unfortunately, this technique has limited precision for polydisperse samples, such as soil, thus resulting in the characterization of only small particles of soil, at the micron range and below (Kretzschmar et al., 1998; Nguyen et al., 2017, 2013). In addition, to attain the soil dispersion in liquid media for LS analysis, it is necessary to use strong acids, oxidizing agents and/or salts (Kretzschmar et al., 1998; Ngolejeme and Ekosse, 2015; Nguyen et al., 2017, 2013; van Reeuwijk, 2002). Conversely, modern electron microscopy approaches are suitable for revealing, in great detail, soil particle morphology, as well as their elemental composition, by means of X-ray energy-dispersive spectroscopy (EDS) coupled to the microscope. However, these approaches are limited by the low sampling of particles imaged at high magnifications, in the case of both scanning and transmission electron microscopy (SEM and TEM, respectively) (Archanjo et al., 2014; Gilkes, 1994; Yang et al., 2016). In order to negate this issue, new microscopy approaches must image soil particles in a large sampling and at multiple length scales to determine particle compositions and reveal their morphologies from micrometers to centimeters. As recently shown by our group, this can be currently achieved by large-field (LF) X-ray imaging in combination with image analysis algorithms (Noronha et al., 2017; N.C. Oliveira et al., 2015; Sousa et al., 2017). Thus, by applying this approach for soil samples, one can unveil direct or indirect fertility aspects, especially those related to the sustainability of fertility, i.e., the "storage" of elements, such as carbon, phosphorus, nitrogen and calcium, which are present as particles (Kern and Kämpf, 1989). On this basis, with regards to the biology, physics and chemistry influencing soil fertility, LF imaging can unveil several aspects of the latter two with great precision.

Considering the perspectives presented for the LF imaging, we used here this approach in an attempt to assess the remarkable fertility capacities of Amazonian soil "Terra Mulata de Índio" (TMI), by imaging the soil particles ex-situ. It is known that this anthropogenic soil (i.e., Anthrosol) presents a sustained fertility in determined rims and is characterized by a high concentration of stable organic matter, phosphorus, calcium and contains the presence of potsherds (Hastik et al., 2013; Taube et al., 2013). However, there is no precise information on the PSDs of Amazonian Anthrosols. Furthermore, the composition and morphological characteristics of TMI were compared to oxisol and ultisol, which were collected from different regions of Brazil. A sequential scanning of the subjacent areas of the pelletized soil samples (with no chemical processing) was performed over the whole specimens $(10 \mathrm{~mm}$ diameter disks). Computational analyses of the LF images further revealed, at multiple length scales (micrometers to millimeters), the soil particle compositions, morphologies and PSDs. In addition, a comparative-quantitative analysis of all detected elements (e.g., calcium, potassium and magnesium) in all samples could be performed with great precision due to the LF scanning. Therefore, a fingerprint of the nutrients and other elements/compounds present in soils of high and sustained fertility, such as TMI, could be obtained. Raman spectroscopy was also carried out to complement the above information in terms of structural information of the soils. The knowledge provided by this work is crucial to determine the suitable morphological and structural characteristics of possible soil amendments, such as biochar (Archanjo et al., 2014; Atkinson et al., 2010; Hernandez-Soriano et al., 2016; Meyer et al., 2011; Yang et al., 2016), which can improve soil fertility as well as carbon sequestration in the future.

\section{Materials and methods}

\subsection{Soil sample collection and preparation}

Soil samples representative of oxisol from Maringá (Paraná State; $23^{\circ} 23^{\prime} 16.63^{\prime \prime} \mathrm{S}$ and $51^{\circ} 59^{\prime} 29.37^{\prime \prime} \mathrm{W}$ ), ultisol from São Jose do Rio Preto (São Paulo State; $20^{\circ} 48^{\prime} 19.79^{\prime \prime} S$ and $49^{\circ} 19^{\prime} 43.51^{\prime \prime} \mathrm{W}$ ) and TMI from the Amazon (Amazonas State) were sampled from three different places in Brazil, as shown in Fig. 1. Soil samples from the Amazon (SISBio authorization by Chico Mendes Institute for Biodiversity Conservation, Ministry of the Environment, No. 50042-2) were collected in an area of native forest (named TMI-1; $3^{\circ} 04^{\prime} 05.17^{\prime \prime} \mathrm{S}$ and $58^{\circ} 34^{\prime} 11.68^{\prime \prime} \mathrm{W}$ ) and in an open area with only undergrowth (named TMI-2; $3^{\circ} 04^{\prime} 05.45^{\prime \prime S}$ and $58^{\circ} 33^{\prime} 51.11^{\prime \prime}$ W). Oxisol and ultisol were classified according to the Soil Survey Staff (2014), and are equivalent to "Latossolo" and "Argissolo", respectively, in the Brazilian System of Soil Science (EMBRAPA Brazilian Agricultural Research Corporation, 2013).

Soil samples from each studied area were collected at a $0.00-0.30 \mathrm{~m}$ depth. After the soil was air-dried, it was sieved with a 10-mesh $(2 \mathrm{~mm})$ sieve to remove only large plant residues, stones and potsherds. Finally, $0.5 \mathrm{~g}$ soil samples (triplicate) were pelletized into disks of $10 \mathrm{~mm}$ in diameter and further introduced in the SEM chamber without sample preparation.
TMI-1

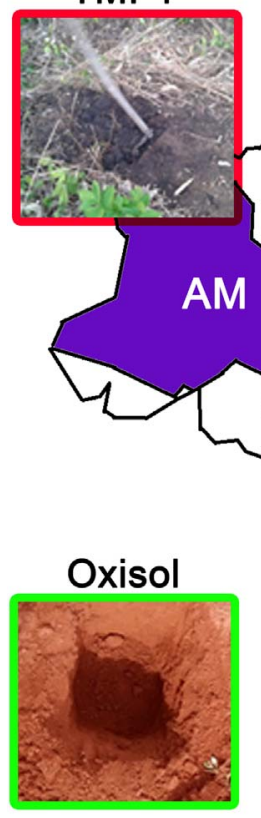

TMI-2

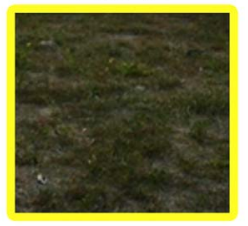

Fig. 1. Collection sites of Brazilian soils: ultisol (São José do Rio Preto, São Paulo State), oxisol (Maringá, Paraná State) and Amazonian dark earth TMI (Itacoatiara, Amazonas State). TMI soils were collected in an area of native forest (TMI-1) and in an open area with only undergrowth (TMI-2). 

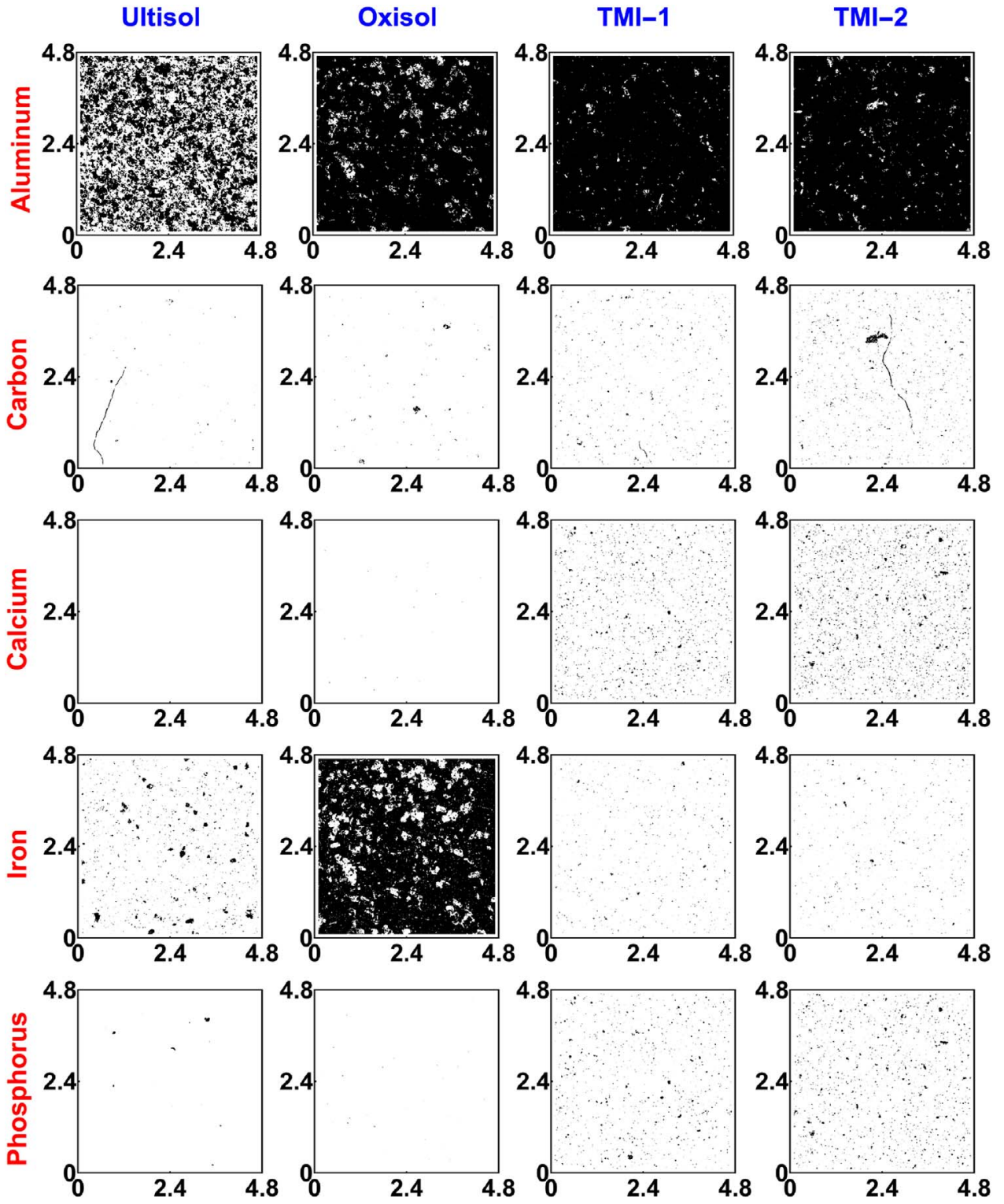

Fig. 2. Binarized LF X-ray images (elemental maps of $\mathrm{Al}, \mathrm{C}, \mathrm{Ca}, \mathrm{Fe}$, and $\mathrm{P}$ ) of Brazilian soil samples ultisol, oxisol, TMI-1 and TMI-2, represented as a function of the elements. X-Y graphic scales are provided in millimeters. These maps indicate the presence (in black) of particles in soil samples.

\subsection{LF X-ray imaging of Brazilian soils}

The X-ray signal was supplied from EDS and recorded along a LF scan performed with an electron microscope Quanta-450 with a fieldemission gun, a $100 \mathrm{~mm}$ stage and an X-ray detector (model 150, Oxford). Pelletized soil samples (disks) were introduced in the microscope chamber without sample preparation. Scans were performed in low-vacuum mode (approximately $100 \mathrm{~Pa}$ of water vapor) to prevent sample charging. The scans were performed at a beam acceleration voltage of $20 \mathrm{kV}$ and with a condenser aperture of $50 \mu \mathrm{m}$. For $20 \mathrm{kV}$ of acceleration voltage, the beam current over the specimen was about $10 \mathrm{nA}$. For increasing the beam high-vacuum path and minimizing spurious beam skirting in the chamber (at $100 \mathrm{~Pa}$ ), a gaseous analytical cone (i.e., GAD) was used in all scans. The EDS detector was inserted at a collection angle of $55^{\circ}$ with the column axis positioned approximately at the end of the polar piece. In all analyses, the working distance was set at approximately $10 \mathrm{~mm}$. The LF electron scan was performed along an $8 \times 8 \mathrm{~mm}$ area over the disks of pelletized soils, and the LF scan took about $10 \mathrm{~h}$ for each pellet. The image definition and sensitivity are largely increased along the LF scan, since the resulting data contains cumulative signals from $>800$ X-ray images and EDS spectra. Individual scans had horizontal and vertical fields of 0.411 and
$0.283 \mathrm{~mm}$, respectively, and a definition of $512 \times 352$ pixels. The signal-to-noise ratio is also largely increased along the LF scan, which enables the imaging of elements in low concentrations $(<1 \%)$ or even trace elements. A detailed description of the assembly process for generating the LF X-ray images was provided by our group in previous works (Noronha et al., 2017; N.C. Oliveira et al., 2015; Sousa et al., 2017). In addition, all image-processing steps used in this work are described in the Supporting Information.

\subsection{Raman spectroscopy}

Confocal Raman spectra were acquired using an alpha300 microscope (WITec) equipped with a highly linear $(0.02 \%)$ piezo-driven stage, and an objective lens from Nikon $(100 \times$, NA $=0.90)$. For acquiring the Raman spectra, the TMI-1 and TMI-2 samples were illuminated with a Nd:YAG laser $(2.33 \mathrm{eV}, \lambda=532 \mathrm{~nm})$. The Raman light was detected by a high-sensitivity back-illuminated spectroscopic charge-coupled device behind a $600 \mathrm{~g} / \mathrm{mm}$ grating. The final power at the end of the objective lens used to focus on the TMI samples was $70 \mu \mathrm{W}$. The spectrometer used was an ultra-high-throughput WITec UHTS 300 with up to $70 \%$ throughput, designed specifically for Raman microscopy. The integration time was $0.2 \mathrm{~s} /$ pixel. For the TMI-1 and 
TMI-2 samples, the measured areas are $20 \times 20 \mu \mathrm{m}$ with 60 pixels in each direction.

\subsection{Determination of metals}

Digestion of the soil samples was carried out according to US EPA Method 3050B (USEPA-United States Environmental Protection Agency, 1996). Al, Ca, Cu, Fe, K, Mg, Mn, Na and $\mathrm{Zn}$ concentrations were determined in the samples using a 240FS flame atomic absorption spectrometer (Varian). The laboratory in which these analysis were performed (Laboratório de Estudos em Ciências Ambientais, Instituto de Biociências, Letras e Ciências Exatas, UNESP, Univ. Estadual Paulista, Campus São José do Rio Preto) has participated in proficiency examinations organized by the Brazilian Agricultural Research Corporation (EMBRAPA), for the determination of metals in samples of vegetal tissue and always achieved satisfactory results $(\mathrm{z}<2)$.

\section{Results}

\subsection{Soil particles detection and area distribution in LF X-ray images}

A total of 14 elements were identified in the LF images, i.e., $\mathrm{Al}(\mathrm{K} \alpha)$, $\mathrm{C}(\mathrm{K} \alpha), \mathrm{Ca}(\mathrm{K} \alpha), \mathrm{Cr}(\mathrm{K} \alpha), \mathrm{F}(\mathrm{K} \alpha), \mathrm{Fe}(\mathrm{K} \alpha), \mathrm{Mg}(\mathrm{K} \alpha), \mathrm{Mn}(\mathrm{K} \alpha), \mathrm{Na}(\mathrm{K} \alpha), \mathrm{O}$ $(K \alpha), \mathrm{P}(\mathrm{K} \alpha), \mathrm{S}(\mathrm{K} \alpha), \mathrm{Si}(\mathrm{K} \alpha)$ and $\mathrm{Ti}(\mathrm{K} \alpha)$. Cu could not be properly identified through EDS due to a pulse pile-up effect generated from the combination of $\mathrm{Al} \mathrm{K \alpha}$ and $\mathrm{Si} \mathrm{Ka}$ X-ray photons with that of $\mathrm{Fe} \mathrm{K \alpha}$ (at around $8 \mathrm{keV}$ ). Considering the low concentration of $\mathrm{Cu}$, this pile-up effect prevents the correct signal accumulation to generate the $\mathrm{Cu} \mathrm{Ka}$ peak. The same occurred for K (at around $3.3 \mathrm{keV}$ ) due to the pile-up effect from $\mathrm{Al} \mathrm{K \alpha}$ and Si Ka X-ray photons. In addition, the Zn Ka signal was below the EDS detection limit (at $8.6 \mathrm{keV}$ ). On this basis, these elements were identified and quantified (relative concentration) by atomic absorption spectrometry (AAS; see Table S1 in the Supporting information).

The visualization of particles in raw maps $(8 \times 8 \mathrm{~mm})$ is difficult to perform, especially for elements that have micrometer nanoparticles (C, $\mathrm{Cr}$, Ca, P and Ti, see an example for carbon in Fig. S1 in the Supporting information). As a result, images are represented with a reduced size, representing a sample area of $4.8 \times 4.8 \mathrm{~mm}$. LF X-ray images (i.e., elemental maps) representing $\mathrm{Al}, \mathrm{C}, \mathrm{Ca}, \mathrm{Fe}$, and $\mathrm{P}$ are shown in Fig. 2, while those representing $\mathrm{Cr}, \mathrm{F}, \mathrm{Mg}, \mathrm{Mn}, \mathrm{Na}, \mathrm{O}, \mathrm{S}, \mathrm{Si}$ and $\mathrm{Ti}$ are shown in the Figs. S2 and S3 (see the Supporting information).

At the millimeter scale, soil particles are mainly comprised of compounds of $\mathrm{Al}, \mathrm{Si}$ and $\mathrm{O}$. It was evidenced that these elements are homogeneously distributed over the LF images of all soil samples and comprise the major elements distributed in the samples (see in Figs. 2, and S2 and S3 in the Supporting information). In addition, the $\mathrm{Al}$ and $\mathrm{Si}$ elemental maps exhibit significant overlapping for all soil samples, since they occur as aluminum silicates (see Fig. S4 in the Supporting information). However, for ultisol, this overlapping is significantly smaller ( $\sim 40 \%$ area) than for the other samples ( $>80 \%$ area), thus indicating that the major part of $\mathrm{Si}$ in ultisol is not present as aluminum silicates. In addition to these major elements, the presence of particles was also observed for C, Ca, Cr, F, Fe, Mg, Mn, Na, O, P, S and Ti, although these elements occupy a small portion of the scanned area (except for Fe in oxisol, which is largely distributed in the sample; see Figs. 2, and S2 and S3 in the Supporting Information). The Al, Si and O distributions in the $\%$ area of the LF images were $\geq 90 \%$, with the exception of $\mathrm{Al}$ for ultisol (37.6\%; see Table 1). Fe was largely distributed in LF images of oxisol (58.4\%). All other elements occupied $<2 \%$ area of the LF images for all samples (see Table 1 ).

\subsection{Relative concentration of soil elements from LF scanning}

The relative concentrations of elements were calculated through the integration and correlation of the peak areas present in the cumulative
Table 1

Area distribution of elements in soil samples.

\begin{tabular}{|c|c|c|c|c|}
\hline \multirow[b]{2}{*}{ Elements } & \multicolumn{4}{|c|}{$\begin{array}{l}\text { Percentage of the total area occupied by particles } \\
(\% \text { area })^{\mathrm{a}}\end{array}$} \\
\hline & Ultisol & Oxisol & TMI-1 & TMI-2 \\
\hline $\mathrm{Al}$ & $37.6(1.94)$ & $89.1(2.32)$ & $94.1(1.66)$ & $90.5(3.56)$ \\
\hline $\mathrm{C}$ & $0.10(0.07)$ & $0.08(0.06)$ & $0.29(0.16)$ & $0.44(0.08)$ \\
\hline $\mathrm{Ca}$ & b & b & $0.75(0.14)$ & $1.33(0.34)$ \\
\hline $\mathrm{Cr}$ & $0.06(0.02)$ & $0.03(0.02)$ & b & b \\
\hline $\mathrm{F}$ & b & b & b & b \\
\hline $\mathrm{Fe}$ & $1.47(0.31)$ & $58.4(27.7)$ & $0.27(0.02)$ & $0.24(0.06)$ \\
\hline $\mathrm{Mg}$ & b & b & b & b \\
\hline $\mathrm{Mn}$ & b & b & b & b \\
\hline $\mathrm{Na}$ & b & b & $0.01\left(^{b}\right)$ & b \\
\hline $\mathrm{O}$ & $83.0(1.98)$ & $97.7(0.44)$ & $99.1(0.49)$ & $97.8(1.67)$ \\
\hline$P$ & $0.03(0.01)$ & $\mathrm{b}$ & $0.60(0.09)$ & $1.00(0.26)$ \\
\hline S & b & b & b & b \\
\hline $\mathrm{Si}$ & $93.0(1.59)$ & $98.0(0.44)$ & $99.3(0.37)$ & 98.4 (1.19) \\
\hline $\mathrm{Ti}$ & $1.40(0.25)$ & $1.36(0.39)$ & $0.25(0.03)$ & $0.20(0.04)$ \\
\hline
\end{tabular}

a Values in parentheses are the standard deviation.

b Small values (bellow $0.01 \%$ area).

EDS spectra (see Fig. 3). This cumulative signal is a result of the summation of all spectra acquired along the LF scan for each soil sample, which largely increases the precision of the analysis (N.C. Oliveira et al., 2015). For those elements with a concentration exceeding $0.5 \mathrm{wt}$ $\%$, their relative concentrations in regard to the weight are provided in Table 2. Considering the major elements, it was observed that the $\mathrm{Si} / \mathrm{Al}$ and $\mathrm{Si} / \mathrm{O}$ ratios are substantially higher in ultisol compared to the other samples (also see Fig. S4 in the Supporting information). This fact, along with the lower concentration of $\mathrm{Al}$ found by atomic absorption spectrometry (see Table S1 in the Supporting information), confirm that aluminum silicates are less abundant in this sample. In addition, important differences between the soil samples were found for the relative concentrations of minor elements, like C, Ca, Cr, F, Fe, Mg, Mn, Na, P, S and $\mathrm{Ti}$ (see Fig. 3b). The relative concentrations of $\mathrm{C}, \mathrm{Ca}$ and $\mathrm{P}$ were higher in TMI-1 and TMI-2, while the relative concentrations of F, Fe and $\mathrm{Ti}$ were higher in oxisol. A higher concentration of Fe in oxisol was also confirmed by atomic absorption spectrometry (see Table S1 in the Supporting information) (Roscoea and Buurmanb, 2003).

\subsection{Soil particle size distribution functions (PSDs)}

When analyzing the soil particles through PSDs from a particle minimum cross-section area of $2.5 \mu \mathrm{m}^{2}$, it was observed that Al-based particles of up to $200 \mu \mathrm{m}^{2}$ occur in a larger amount in ultisol, while in other samples, the sizes lay below $100 \mu \mathrm{m}^{2}$ (see Figs. 4 and S5 in the Supporting information). The same pattern occurs for Si-based particles, where TMI-1 had fewer particles $\left(<100 \mu \mathrm{m}^{2}\right)$. For minor elements, the presence (i) of Cr-based particles in all samples $\left(<200 \mu \mathrm{m}^{2}\right)$ and (ii) Ti-based particles mainly in the oxisol sample $\left(<200 \mu \mathrm{m}^{2}\right)$ was observed. Particles comprised of $\mathrm{Cr}, \mathrm{F}, \mathrm{Mg}, \mathrm{Mn}, \mathrm{Na}$ and S were identified in a significantly reduced quantity in all soil samples. A large concentration of C, Ca and P particles (of up to $100 \mu \mathrm{m}^{2}$ ) was found in TMI-1 and TMI-2 (see columns 3 and 4 in Fig. 4). In the case of the C-, Ca- and P-based particles, along with the increase in the particle number (see Fig. 4), the mean distance between neighboring particles (i.e., the closest particles) decreases in TMI-1 and TMI-2 to values of about $40-70 \mu \mathrm{m}$, while these values were of hundreds of microns in ultisol and oxisol (see Table 3).

\subsection{Raman spectroscopy of carbon particles in Amazonian Anthrosols}

In order to assess the chemical structure of carbon particles in soils in greater detail, thousands of Raman spectra were taken at the micrometer length scale for TMI-1 and TMI-2. Raman spectroscopic 

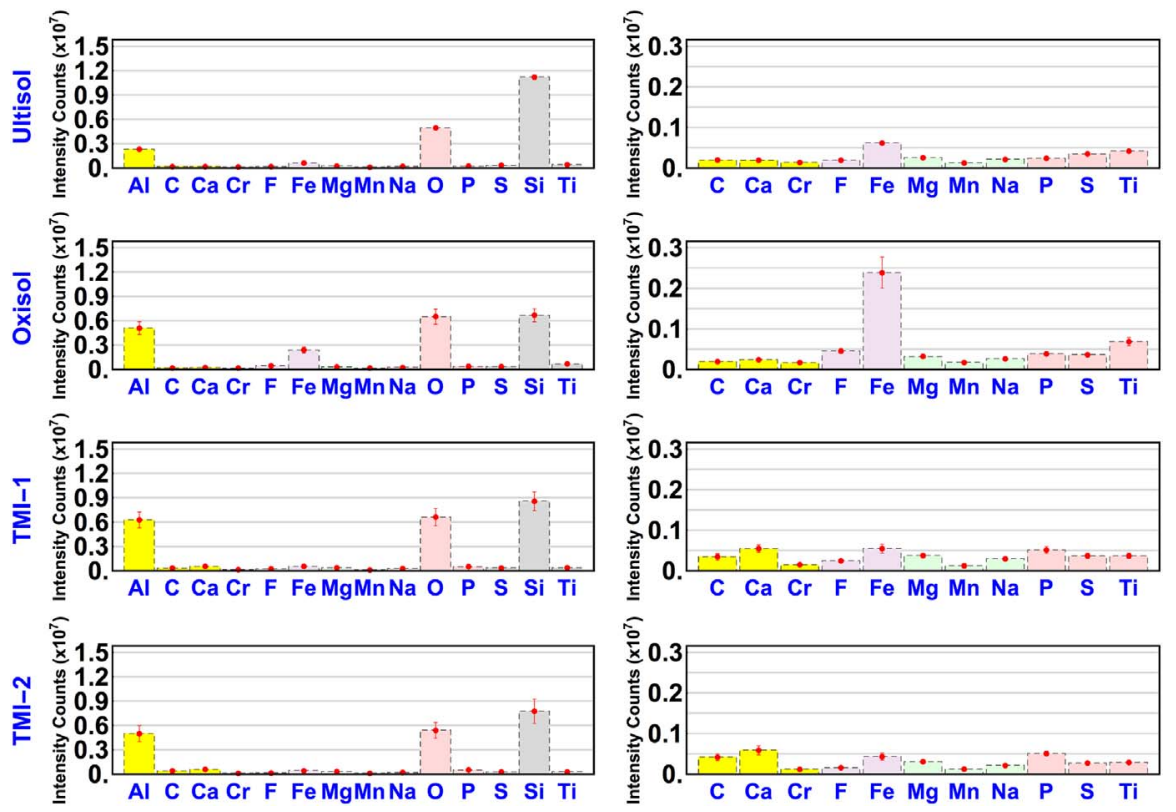

Fig. 3. Concentration of all identified elements (in intensity counts) present in Brazilian soil samples calculated from the integration of LF X-ray images (left). Concentration of soil minor elements (in intensity counts) represented in a magnified Y-scale (right). Red bars in the graphics represent standard deviations calculated from at least three LF scans performed for independent sample specimens. (For interpretation of the references to colour in this figure legend, the reader is referred to the web version of this article.)

Table 2

Relative concentration of elements detected by EDS.

\begin{tabular}{|c|c|c|c|c|c|c|c|c|c|}
\hline & \multirow{2}{*}{$\begin{array}{l}\mathrm{AM}^{\mathrm{a}} \\
\left(\mathrm{g} \mathrm{mol}^{-1}\right)\end{array}$} & \multicolumn{2}{|c|}{ Ultisol } & \multicolumn{2}{|l|}{ Oxisol } & \multicolumn{2}{|l|}{ TMI-1 } & \multicolumn{2}{|l|}{ TMI-2 } \\
\hline & & wt $\%^{\mathrm{b}}$ & $\begin{array}{l}\mathrm{NC} \\
(\mathrm{mol})^{\mathrm{c}}\end{array}$ & $w \mathrm{t}^{\mathrm{b}}{ }^{\mathrm{b}}$ & $\begin{array}{l}\mathrm{NC} \\
(\mathrm{mol})^{\mathrm{c}}\end{array}$ & wt $\%^{\mathrm{b}}$ & $\begin{array}{l}\mathrm{NC} \\
(\mathrm{mol})^{\mathrm{c}}\end{array}$ & wt $\%^{\mathrm{b}}$ & $\begin{array}{l}\mathrm{NC} \\
(\mathrm{mol})^{\mathrm{C}}\end{array}$ \\
\hline $\mathrm{C}$ & 12.0 & 20.9 & 69.5 & 17.4 & 40.8 & 22.6 & 150.2 & 23.9 & 158.8 \\
\hline $\mathrm{O}$ & 15.99 & 43.3 & 108.0 & 42.3 & 74.5 & 46.8 & 233.4 & 44.1 & 219.9 \\
\hline $\mathrm{F}$ & 18.99 & 1.8 & 3.8 & 2.0 & 3.0 & 1.9 & 8.0 & 1.7 & 7.1 \\
\hline $\mathrm{Na}$ & 22.99 & d & - & d & - & d & - & d & - \\
\hline $\mathrm{Mg}$ & 24.30 & $\mathrm{~d}$ & - & d & - & d & - & $\mathrm{d}$ & - \\
\hline $\mathrm{Al}$ & 26.98 & 4.3 & 6.4 & 9.8 & 10.2 & 10.0 & 29.6 & 9.5 & 28.1 \\
\hline $\mathrm{Si}$ & 28.08 & 24.4 & 34.7 & 13.2 & 13.2 & 14.6 & 41.5 & 15.5 & 44.0 \\
\hline $\mathrm{P}$ & 30.97 & d & - & d & - & 0.5 & 1.3 & 0.7 & 1.8 \\
\hline S & 32.06 & d & - & d & - & d & - & d & - \\
\hline $\mathrm{Ca}$ & 40.07 & d & - & d & - & 0.7 & 1.4 & 1.2 & 2.4 \\
\hline $\mathrm{Ti}$ & 47.86 & 1.2 & 1.0 & 1.7 & 1.0 & 0.6 & 1.0 & 0.6 & 1.0 \\
\hline $\mathrm{Cr}$ & 51.99 & $\mathrm{~d}$ & - & $\mathrm{d}$ & - & $\mathrm{d}$ & - & d & - \\
\hline Mn & 54.93 & $\mathrm{~d}$ & - & d & - & $\mathrm{d}$ & - & $\mathrm{d}$ & - \\
\hline $\mathrm{Fe}$ & 55.84 & 3.5 & 2.5 & 13.0 & 6.6 & 2.0 & 2.9 & 2.3 & 3.3 \\
\hline
\end{tabular}

${ }^{\mathrm{a}}$ Atomic mass.

${ }^{\mathrm{b}} \mathrm{wt} \%$ values are relative concentrations obtained by a standardless method, after the correlation of all EDS peaks intensities.

${ }^{\mathrm{c}}$ Normalized relative molar concentrations (NC, in molar units) were calculated by dividing each wt\% value by the atomic mass $\left(\mathrm{g} \mathrm{mol}^{-1}\right)$ of each element, and then by normalizing the results in regard to the element present in the smallest quantity.

${ }^{\mathrm{d}} \mathrm{wt} \%$ values for elements present in low concentrations $(<0.5 \mathrm{wt} \%$ ) could not be quantitatively interpreted due to the precision of EDS, though they could be detected.

images of the integrated areas of the G- (around $1590 \mathrm{~cm}^{-1}$ ) and Dbands (around $1360 \mathrm{~cm}^{-1}$ ) present in TMI-1 and TMI-2 are shown in Fig. 5. This figure clearly shows the correlation between the darker areas in the optical images and the G- and D-band maps. The acquired spectra for several carbon particles at the micrometer length scale for TMI-1 and TMI-2 indicated a high sp ${ }^{2}$ to $\mathrm{sp}^{3}$ ratio, considering both the G-band frequency and its full width at half maximum (Ribeiro-Soares et al., 2013). Furthermore, a disordered chemical structure was also confirmed, since the maps of the G- and D-bands largely overlap on all particles imaged. The Raman spectra shown in Fig. $5 \mathrm{~g}$ are very similar, although for TMI-1, a variation in the relative intensity of the G- and Dbands (points P1 and P2, indicated by arrows) was observed. This is a clear indication of the heterogeneity of the structural disorder for carbon particles in this type of soil. Considering that $\mathrm{C}$ and $\mathrm{O}$ maps do not have a perfect overlap in the LF X-ray images for TMI-1 and TMI-2 (see Fig. S6 in the Supporting information), it must be considered that this structural disordered identified for carbon particles is also related to a lack of crystallinity caused by defects other than those introduced by oxidation.

\section{Discussion}

Through LF X-ray imaging for ultisol, oxisol and Amazonian dark earth "Terra Mulata de Índio", it was evidenced that striking differences occur in the particles among the samples. Regarding the fertility, the large amount of C-, Ca- and P-based particles in TMI-1 and TMI- 2 must be considered. In addition, potsherds were found in TMI-1 and TMI-2. It is important to mention that the TMI- 1 and TMI- 2 samples were collected from sites that were $3 \mathrm{~km}$ apart at most. A possible role of the potsherds on the release of nutrients in TMI-1 and TMI-2 soils should not be ignored, considering that they have $9.5 \mathrm{wt} \% \mathrm{C}, 3.9 \mathrm{wt} \% \mathrm{Fe}, 1.5 \mathrm{wt} \% \mathrm{Ca}$ and $1.1 \mathrm{wt}$ \% P (see Fig. S7 in the Supporting information) in their compositions. Valente and Costa (2017) investigated the role of ceramic fragments (sherds) on the fertility of anthropogenic soils from Amazon basin. These authors quantified exchangeable $\mathrm{K} \quad\left(0.3-1.6 \mathrm{cmol} \mathrm{kg}^{-1}\right)$, Ca $\left(0.2-27 \mathrm{cmol} \mathrm{kg}^{-1}\right), \mathrm{Mg}\left(0.02-1.4 \mathrm{cmol} \mathrm{kg}^{-1}\right), \mathrm{Zn}\left(0.05-13.5 \mathrm{mg} \mathrm{kg}^{-1}\right)$, Mn (3-56 mg kg-1) and available P (1.0-2550 $\mathrm{mg} \mathrm{kg}^{-1}$ ) in 44 samples (Valente and Costa, 2017). Comparatively, the TMI soils also contain a significantly larger amount of $\mathrm{C}$, as well as other elements, such as $\mathrm{Ca}$ and P (Glaser et al., 2001; Lehmann et al., 2003; Steiner, 2007). These are the key elements influencing the production potential and fertility of most soils.

The Ca concentrations in TMI- 1 and TMI- 2 were at least $14 \times$ larger in comparison to the other soil samples, as calculated by atomic absorption spectrometry (see Table S1 in the Supporting information), and this element is present in these soils mainly as particles (see columns 3 and 4 in Fig. 4). In addition, the Ca particles identified in LF elemental maps largely overlap P particles for TMI-1 and TMI-2, ( $>70 \%$ area; see Fig. S4 in the Supporting information), which indicates that these elements are associated in these samples. We showed that $\mathrm{Ca}$ is present and is associated with $\mathrm{P}$ in micrometric particles of up to $150 \mu \mathrm{m}^{2}$ (see Fig. 4). Interestingly, no overlapping occurred for the other samples ( $\sim 0 \%$ area; see Fig. S4 in the Supporting information). Although it was previously shown that $\mathrm{Ca}$ and $\mathrm{C}$ can occur and are associated in nanoparticles (of hundreds of nanometers) in Amazonian dark earth "Terra Preta de Índio" (TPI) (Archanjo et al., 2014; Jorio et al., 2012), after processing the LF X-ray images in this study no 

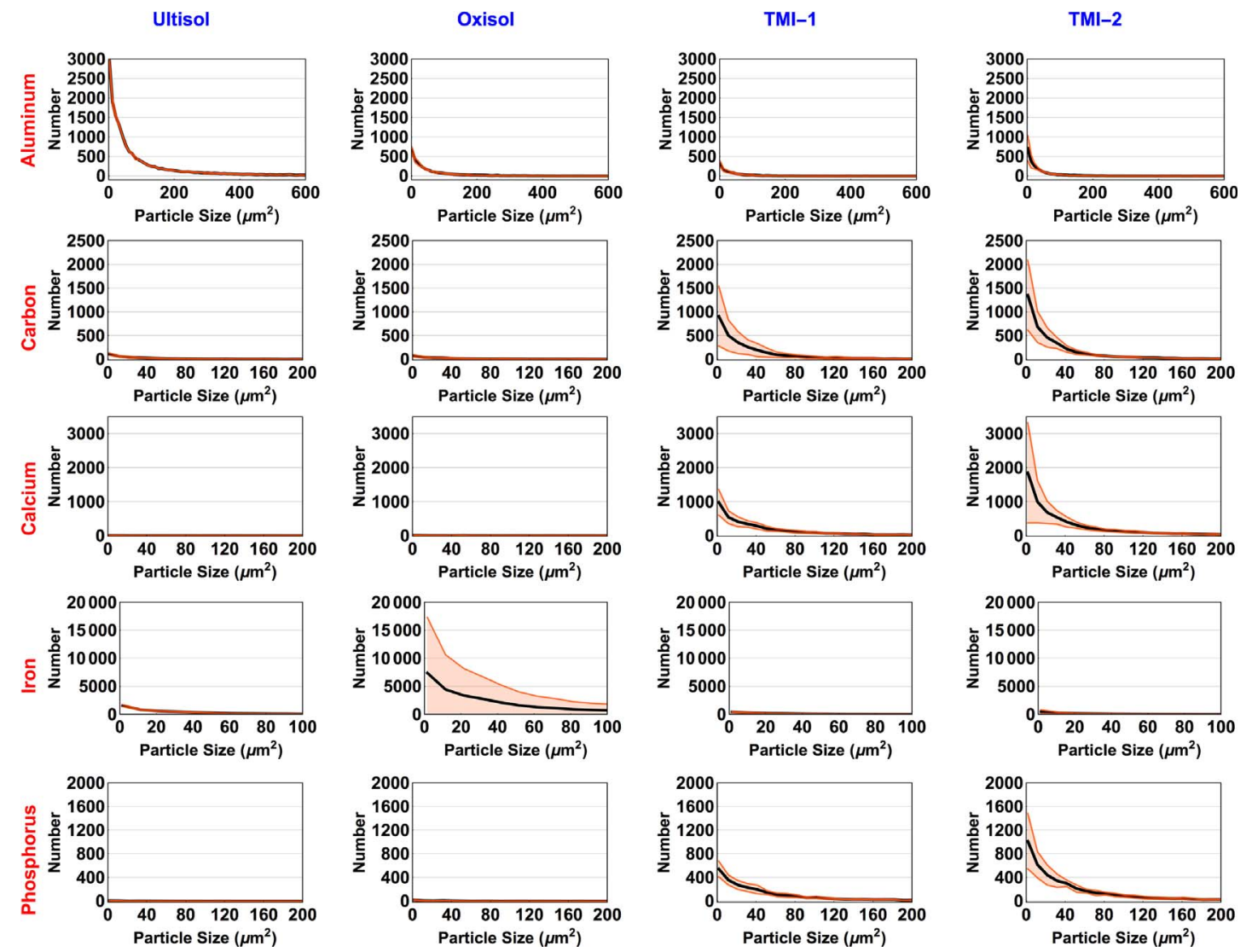

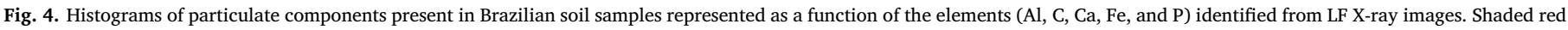

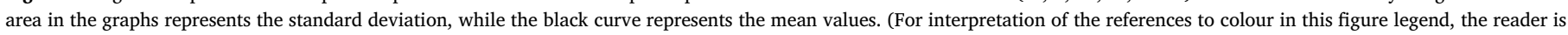
referred to the web version of this article.)

Table 3

Dimensional analysis of the particles in soil samples.

\begin{tabular}{lllll}
\hline \multirow{4}{*}{ Minor elements } & \multicolumn{4}{l}{$\begin{array}{l}\text { Mean distance between nearest neighbor particles } \\
(\mu \mathrm{m})^{\mathrm{a}}\end{array}$} \\
\cline { 2 - 5 } & Ultisol & Oxisol & TMI-1 & TMI-2 \\
\hline $\mathrm{C}$ & $175(205)$ & $190(194)$ & $59.1(50.8)$ & $45.7(39.0)$ \\
$\mathrm{Ca}$ & $\mathrm{b}$ & $333(459)$ & $57.0(35.8)$ & $43.1(26.4)$ \\
$\mathrm{Cr}$ & $186(154)$ & $251(282)$ & $338(446)$ & $399(326)$ \\
$\mathrm{F}$ & $390(214)$ & $363(492)$ & $553(445)$ & $255(269)$ \\
$\mathrm{Fe}$ & $41.0(32.1)$ & $16.6(12.5)$ & $84.6(62.9)$ & $85.7(59.8)$ \\
$\mathrm{Mg}$ & $664(810)$ & $898(668)$ & $368(203)$ & $454(417)$ \\
$\mathrm{Mn}$ & $\mathrm{b}$ & $70.6(135)$ & $634(315)$ & $416(444)$ \\
$\mathrm{P}$ & $468(587)$ & $601(417)$ & $70.6(44.2)$ & $54.1(35.3)$ \\
$\mathrm{S}$ & $\mathrm{b}$ & $\mathrm{b}$ & $\mathrm{b}$ & $\mathrm{b}$ \\
$\mathrm{Ti}$ & $84.3(57.4)$ & $32.7(17.5)$ & $77.8(44.7)$ & $100(58.8)$ \\
\hline
\end{tabular}

${ }^{a}$ Values in parentheses are the standard deviation.

${ }^{\mathrm{b}}$ A low amount of detected particles prevent the calculation.

overlapping was detected when $\mathrm{C}$ and Ca maps were combined at large length scales. This result has also been observed in another study of TPI (Archanjo et al., 2015).

The Ca to P molar ratio calculated for several particles identified in TMI-1 and TMI-2 varied from 1.2 to 2.2. This ratio was calculated from the summation of contrast values (in grayscale) present in all pixels that comprise the particle. On this basis, the presence of $\mathrm{Ca}$ and $\mathrm{P}$ associated in calcium phosphates particles (e.g. $\mathrm{Ca}_{3}\left(\mathrm{PO}_{4}\right)_{2}, \mathrm{Ca}_{10}\left(\mathrm{PO}_{4}\right)_{6}(\mathrm{OH})$ ) must be considered. The occurrence of $\mathrm{Ca}$ adsorbed to particles must also be considered to a lesser extent (Archanjo et al., 2014). The origin of Ca-P particles in Anthrosols, such as TMI, can be related with an initial deposition of animal and fish bones, which transform from crystalline and thermodynamically stable forms to soluble forms of Ca-P with time (Sato et al., 2009; Walker and Syers, 1976).

In regard to the micrometric C-based particles identified in TMI-1 and TMI-2, recent studies on TPI indicated that the chemical structure of carbon particles in this soil could be classified as if it is at the limit between nanographite and amorphous carbon, considering the scale of the amorphization process (Ribeiro-Soares et al., 2013). The G-band is one of the most characteristic vibrational modes in graphitic materials and can reveal the degree of $\mathrm{sp}^{2}$ hybridization (tangential stretching mode), while the D-band indicates the degree of disorder in the graphitic structure (Allen et al., 2010; Jorio et al., 2012). The latter is related to the presence of dangling bonds, doping, and most importantly, to the degree of oxidation of the graphitic sheet (Andrade et al., 2013; Archanjo et al., 2015; Faria et al., 2012; Paula et al., 2011). More specifically, oxidation results from the formation of oxygenated groups in the structure of the carbon particles, which include the presence of alcohols, ketones, carboxylic acids, phenols and anhydrides (Chen et al., 2012; Ros et al., 2002).

The lack of a perfect overlap between C and O maps in the LF X-ray images of TMI-1 and TMI-2 (mean values below 90\% area; see Fig. S6 in the Supporting information) indicates that carbon particles are not totally oxidized, thus supporting these previous findings that were drawn at smaller length scales (micrometers). Regions over which $\mathrm{O}$ and $\mathrm{C}$ maps overlap result from the presence of oxygenated groups, such as carboxylic acids, ketones, alcohols, ethers, esters and others (Archanjo et al., 2014), which controls several diffusion process in the soil by means of sorption events occurring from interactions with these oxygenated groups (Atkinson et al., 2010; Hernandez-Soriano et al., 2016; Yang et al., 2016). In addition, besides the presence of a large amount of $\mathrm{C}$ as particles, this fine tuning of the $\mathrm{sp}^{2}$ to $\mathrm{sp}^{3}$ ratio in carbon particles is also related to the long-term fertility of Amazonian dark earths. 

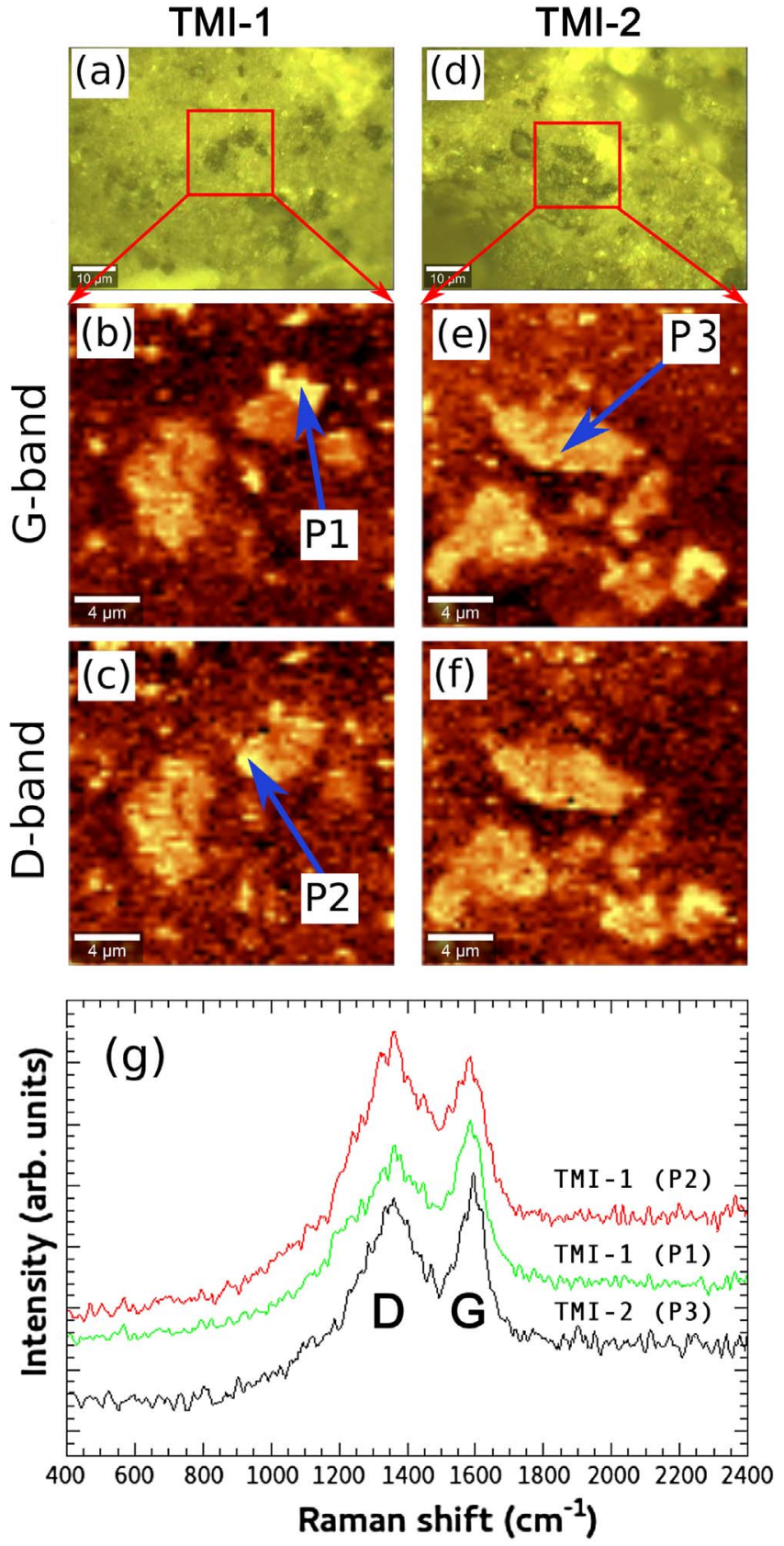

Fig. 5. Optical micrographs (first row) of micrometric carbon particles and the corresponding maps (second and third rows) of the G- and D-bands acquired through Raman spectroscopy for soil samples (a, b and c) TMI-1 and (d, e and f) TMI-2. (g) Cumulative Raman spectra for TMI-1 and TMI-2 (G- and D-bands are depicted) given by the indicated points.

Micrometric particles based on C, Ca and P that were identified in a large amount in TMI-1 and TMI-2 can act as carbon and nutrient "storage" systems in soil (Haynes and Naidu, 1998; Taube et al., 2013). In the case of oxidized C-based particles, besides providing organic compounds to the soil, they can also act in the long-term sequestration of $\mathrm{C}, \mathrm{Fe}$ and $\mathrm{Al}$, and the stabilization of microorganisms (Atkinson et al., 2010; Yang et al., 2016). Furthermore, they can possibly provide benefits similar to those associated with biochar, which involve improvement of soil $\mathrm{pH}$ and cation exchange capacity, improvement of soil structure and water retention capacity, and decrease of nutrient loss through leaching and runoff (Glaser, 2014; Lehmann, 2009; PazFerreiro et al., 2014; Sohi et al., 2010). Enhancement of crop productivity with biochar soil amendment has also been attributed to soil fertility improvement through the improved availability of basic nutrients, such as Ca and Mg in acid soils (Glaser et al., 2002; Major et al., 2010), increased $\mathrm{N}$ and P retention and N-use efficiency (Hossain et al., 2010; van Zwieten et al., 2010; Zhang et al., 2010), increased enzymatic activity (Paz-Ferreiro et al., 2012), and the improvement of the soil moisture regime (Zhang et al., 2012). Finally, previously reported high productivity increase of sandy soils with biochar could be a result of the enhanced organic matter storage, which could have promoted soil aggregation and retention both of nutrients and moisture (Gaskin et al., 2009; Oguntunde et al., 2004; van Zwieten et al., 2010). These properties are of special importance considering soil loss and degradation due to agriculture, which has reduced soil organic matter, biodiversity, water retention capacity and soil vitality for crop production around the world (Bruun et al., 2015; Cerdà et al., 2009; Colazo and Buschiazzo, 2015; S.P. Oliveira et al., 2015).

In addition, as $\mathrm{P}$ is one of the most limiting nutrients to plants grown in soils, especially in highly weathered acid soils in the tropics (Vitousek and Sanford, 1986), the presence of a high amount of micrometer P-based particles must be accounted for the manifestation of high fertility in TMI soils. In plants, macronutrient $\mathrm{P}$ plays a role in a wide array of processes, including energy generation, nucleic acid synthesis, photosynthesis, glycolysis, respiration, membrane synthesis and stability, enzyme activation/inactivation, redox reactions, signaling, carbohydrate metabolism and N fixation (Bieleski, 1973; Raghothama and Karthikeyan, 2005; Schachtman et al., 1998).

\section{Conclusion}

In order to fully assess the particles in soils samples, we applied a LF X-ray imaging approach by means of a scanning electron microscope (without any chemical processing of the sample), along with the computational analysis of the resulting high-definition maps $(4800 \times 4800$ pixels) related to elements $\mathrm{Al}, \mathrm{C}, \mathrm{Ca}, \mathrm{Cr}, \mathrm{F}, \mathrm{Fe}, \mathrm{Mg}, \mathrm{Mn}$, $\mathrm{Na}, \mathrm{O}, \mathrm{P}, \mathrm{S}, \mathrm{Si}$ and Ti. As the electron scanning was performed over an $8 \times 8 \mathrm{~mm}$ area, it was possible to detect $>10,000$ particles in the LF images of all soil samples. By comparing the morphology of the particles in an ultisol, oxisol and Amazonian dark earth TMI, the presence of large particles (up to $100 \mu \mathrm{m}^{2}$ in cross-section area) in the latter, comprised of $\mathrm{C}, \mathrm{Ca}$ and $\mathrm{P}$, became evident. These particles had a mean distance between closest particles in the order of $40-70 \mu \mathrm{m}$, while this value was in the range of $170-600 \mu \mathrm{m}$ for oxisol and ultisol. Our findings also indicate that C-based micrometric particles found in TMI were not completely oxidized, thus supporting previous studies made at smaller length scales (i.e., nanometer-micrometer) that indicated the presence of $\mathrm{sp}^{2}$-graphitic carbon in these particles. In addition, Ca was largely present in TMI samples as particles associated to $\mathrm{P}$, possibly in the form of phosphates. By means of this analytical approach we have presented a "fingerprint" of the morphology and structure of particles in the highly fertile TMI, which will largely impact on the rational design and management of soils. Based on these results, improved and sustained fertility can be aimed from the morphological and structural control of soil amendments that will act as storage systems, especially for long-term release of carbon and nutrients, such as phosphorus. Finally, this multiple length scale imaging approach will be important in further studies of soil aging and deterioration by determining the evolution of the soil particles morphology as a function of its use, which is a central issue to guarantee food security in the near future.

\section{Acknowledgements}

This work was supported by the Brazilian Council for Scientific and Technological Development (CNPq) (446800/2014-7), and FUNCAP Nucleus of Excellence on Physico-Chemistry at Extreme Conditions (grant number PRONEX PR2-0101-00006.01.00/15). Furthermore, the authors are grateful for the support from the CAPES and Central Analítica-UFC/CT-INFRA/MCTI-SISNANO/Pró-Equipamentos-CAPES 
and for the financial support granted from São Paulo Research Foundation (FAPESP; grant number Process 2015/22954-1).

\section{Appendix A. Supplementary data}

Supplementary data on the image processing algorithms, LF X-ray images, particle size distributions, and the calculations of the overlapping of elemental maps are available in the Supplementary information file. Supplementary data associated with this article can be found in the online version, at https://doi.org/10.1016/j.geoderma. 2017.09.034.

\section{References}

Abbott, L.K., Murphy, D.V., 2007. What is soil biological fertility? In: Soil Biological Fertility - A Key to Sustainable Land Use in Agriculture. Springer, New York, pp. $1-15$.

Allen, M.J., Tung, V.C., Kaner, R.B., 2010. Honeycomb carbon: a review of graphene Chem. Rev. 110, 132-145. http://dx.doi.org/10.1021/Cr900070d.

Andrade, N.F., Martinez, D.S.T., Paula, A.J., Silveira, J.V., Alves, O.L., Souza Filho, A.G., 2013. Temperature effects on the nitric acid oxidation of industrial grade multiwalled carbon nanotubes. J. Nanopart. Res. 15http://dx.doi.org/10.1007/s11051-013-1761 8. (1761-11).

Archanjo, B.S., Araujo, J.R., Silva, A.M., Capaz, R.B., Falcao, N.P.S., Jorio, A., Achete, C.A., 2014. Chemical analysis and molecular models for calcium - oxygen - carbon interactions in black carbon found in fertile Amazonian anthrosoils. Environ. Sci. Technol. 48, 7445-7452.

Archanjo, B.S., Baptista, D.L., Sena, L.A., Cançado, L.G., Falcão, N.P.S., Jorio, A., Achete, C.A., 2015. Nanoscale mapping of carbon oxidation in pyrogenic black carbon from ancient Amazonian Anthrosols. Environ. Sci.: Processes Impacts 17, 775-779. http:// dx.doi.org/10.1039/C4EM00590B.

Arya, L.M., Paris, J.F., 1981. A physicoempirical model to predict the soil moisture characteristic from particle-size distribution and bulk density data. Soil Sci. Soc. Am. J. Vol. 45, 1023-1030.

Atkinson, C.J., Fitzgerald, J.D., Hipps, N.A., 2010. Potential mechanisms for achieving agricultural benefits from biochar application to temperate soils: a review. Plant Soil 337, 1-18. http://dx.doi.org/10.1007/s11104-010-0464-5.

Bieleski, R.L., 1973. Phosphate pools, phosphate transport, and phosphate availability. Annu. Rev. Plant Physiol. 24, 225-252.

Bruun, T.B., Elberling, B., de Neergaard, A., Magid, J., 2015. Organic carbon dynamics in different soil types after conversion of forest to agriculture. Land Degrad. Dev. 26, 272-283.

Cerdà, A., Flanagan, D.C., Bissonnais, Y., Boardman, J., 2009. Soil erosion and agriculture. Soil Tillage Res. 106, 107-108.

Chaparro, J.M., Sheflin, A.M., Manter, D.K., Vivanco, J.M., 2012. Manipulating the soil microbiome to increase soil health and plant fertility. Biol. Fertil. Soils 48, 489-499. http://dx.doi.org/10.1007/s00374-012-0691-4.

Chen, D., Feng, H.B., Li, J.H., 2012. Graphene oxide: preparation, functionalization, and electrochemical applications. Chem. Rev. 112, 6027-6053. http://dx.doi.org/10. 1021/Cr300115g.

Colazo, J.C., Buschiazzo, D., 2015. The impact of agriculture on soil texture due to wind erosion. Land Degrad. Dev. 26, 62-70.

De Souza, A.M., Filgueiras, P.R., Coelho, M.R., Fontana, A., Winkler, T.C.B., Valderrama, P., Poppi, R.J., 2016. Validation of the near infrared spectroscopy method for determining soil organic carbon by employing a proficiency assay for fertility laboratories. J. Near Infrared Spectrosc. 24, 293-303. http://dx.doi.org/10.1255/jnirs. 1219.

EMBRAPA (Brazilian Agricultural Research Corporation), 2013. Brazilian System of the Soil Science (In Portuguese: Sistema Brasileiro de Classificação de Solos). (Brasilia).

Faria, A.F., Martinez, D.S.T., Moraes, A.C.M., Maia Da Costa, M.E.H., Barros, E.B., Souza Filho, A.G., Paula, A.J., Alves, O.L., 2012. Unveiling the role of oxidation debris on the surface chemistry of graphene through the anchoring of ag nanoparticles. Chem. Mater. 24, 4080-4087. http://dx.doi.org/10.1021/cm301939s.

Gaskin, J.W., Speir, R.A., Harris, K., Das, K.C., Lee, R.D., Morris, L.A., Fisher, D.S., 2009. Effect of peanut hull and pine chip biochar on soil nutrients, corn nutrient status, and yield. Agron. J. 102, 623-633.

Gilkes, R.J., 1994. Transmission electron microscope analysis of soil materials. In: Amonette, J.E., Zelazny, L.W. (Eds.), Quantitative Methods in Soil Mineralogy. Soil Science Society of America, Madison, pp. 177-204.

Gimknez, D., Perfect, E., Rawls, W.J., Pachepsky, Y., 1997. Fractal models for predicting soil hydraulic properties: a review. Eng. Geol. 48, 61-83. http://dx.doi.org/10.1016/ S0013-7952(97)00038-0.

Glaser, B., 2014. Soil biogeochemistry: from molecular to ecosystem level using terra preta and biochar as examples. In: Benkeblia, N. (Ed.), Agroecology, Ecosystems, and Sustainability. CRC Press, Boca Raton, pp. 1-40.

Glaser, B., Haumaier, L., Guggenberger, G., Zech, W., 2001. The "Terra Preta" phenomenon: a model for sustainable agriculture in the humid tropics. Naturwissenschaften 88, 37-41. http://dx.doi.org/10.1007/s001140000193.

Glaser, B., Lehmann, J., Zech, W., 2002. Ameliorating physical and chemical properties of highly weathered soils in the tropics with charcoal - a review. Biol. Fertil. Soils 35 , 219-230.
Gupta, S.C., Larson, W.E., 1979. Estimating soil water retention characteristics from particle size distribution, organic matter percent, and bulk density. Water Resour. Res. 15, 1633-1635.

Hastik, R., Geitner, C., Neuburger, M., 2013. Amazonian dark earths in Bolivia? A soil study of anthropogenic ring ditches near Baures (eastern llanos de Mojos). Erdkunde 67, 137-149. http://dx.doi.org/10.3112/erdkunde.2013.02.03.

Haynes, R.J., Naidu, R., 1998. Influence of lime, fertilizer and manure applications on soil organic matter content and soil physical conditions: a review. Nutr. Cycl. Agroecosyst. 51, 123-137. http://dx.doi.org/10.1023/A:1009738307837.

Hernandez-Soriano, M.C., Kerré, B., Kopittke, P.M., Horemans, B., Smolders, E., 2016. Biochar affects carbon composition and stability in soil: a combined spectroscopymicroscopy study. Sci Rep 6, 25127. http://dx.doi.org/10.1038/srep25127.

Hossain, M.K., Strezov, V., Chan, K.Y., Nelson, P.F., 2010. Agronomic properties of wastewater sludge biochar and bioavailability of metals in production of cherry tomato (Lycopersicon esculentum). Chemosphere 78, 1167-1171.

Hughes, R.E., Moore, D.M., Glass, H.D., 1994. Qualitative and quantitative analysis of clay minerals in soils. In: Amonette, J.E., Zelazny, L.W. (Eds.), Quantitative Methods in Soil Mineralogy. Soil Science Society of America, Madison, pp. 330-359.

Huo, D., Yusheng, L.U., Kingston, H.M., 1998. Determination and correction of analytical biases and study on chemical mechanisms in the analysis of $\mathrm{Cr}(\mathrm{VI})$ in soil samples using EPA protocols. Environ. Sci. Technol. 32, 3418-3423. http://dx.doi.org/10. 1021/es971029e.

Jastrow, J.D., 1996. Soil aggregate formation and the accrual of particulate and mineralassociated organic matter. Soil Biol. Biochem. 28, 665-676. http://dx.doi.org/10. 1016/0038-0717(95)00159-X.

Jáuregui, O., Moyano, E., Galceran, M.T., 1998. Liquid chromatography - atmospheric pressure chemical ionization mass spectrometry for chlorinated phenolic compounds. Application to the analysis of polluted soils. J. Chromatogr. A 823, 241-248.

Jorio, A., Ribeiro-Soares, J., Cançado, L.G., Falcão, N.P.S., Dos Santos, H.F., Baptista, D.L., Martins Ferreira, E.H., Archanjo, B.S., Achete, C.A., 2012. Microscopy and spectroscopy analysis of carbon nanostructures in highly fertile Amazonian anthrosoils. Soil Tillage Res. 122, 61-66. http://dx.doi.org/10.1016/j.still.2012.02.009.

Kahle, M., Kleber, M., Jahn, R., 2002. Review of XRD-based quantitative analyses of clay minerals in soils: the suitability of mineral intensity factors. Geoderma 109, 191-205. http://dx.doi.org/10.1016/S0016-7061(02)00175-1.

Kern, D.C., Kämpf, N., 1989. O efeito de antigos assentamentos indígenas na formação de solos com terra preta arqueológicas na região de Oriximiná - PA. Rev. Bras. Ciênc. Solo 13, 219-225.

Kretzschmar, R., Holthoff, H., Sticher, H., 1998. Influence of pH and humic acid on coagulation kinetics of kaolinite: a dynamic light scattering study. J. Colloid Interface Sci. 202, 95-103. http://dx.doi.org/10.1006/jcis.1998.5440.

Lal, R., 2007. Carbon management in agricultural soils. Mitig. Adapt. Strateg. Glob. Chang. 12, 303-322. http://dx.doi.org/10.1007/s11027-006-9036-7.

Lehmann, J., 2009. Terra preta nova - where to from here? In: Woods, W.I., Teixeira, W.G., Lehmann, J., Steiner, C., Antoinette, W., Rebellato, L. (Eds.), Amazonian Dark Earths: Wim Sombroek's Vision. Springer, New York, pp. 473-486.

Lehmann, J., Kern, D., German, L., McCann, J., Martins, G.C., Moreira, L., 2003. Soil fertility and production potential. In: Lehmann, J., Kern, D.C., Glaser, B., Woods, W.I. (Eds.), Amazonian Dark Earths: Origin, Properties. Management. Kluwer Academic, Dordrecht, pp. 105-124.

Li, S., Gu, X., Zhuang, J., An, T., Pei, J., Xie, H., Li, H., Fu, S., Wang, J., 2016. Distribution and storage of crop residue carbon in aggregates and its contribution to organic carbon of soil with low fertility. Soil Tillage Res. 155, 199-206. http://dx.doi.org/10 1016/j.still.2015.08.009.

Major, J., Rondon, M., Molina, D., Riha, S.J., Lehmann, J., 2010. Maize yield and nutrition during 4 years after biochar application to a Colombian savanna oxisol. Plant Soil 333, 117-128.

Malley, D.F., Yesmin, L., Wray, D., Edwards, S., 1999. Application of near-infrared spectroscopy in analysis of soil mineral nutrients. Commun. Soil Sci. Plant Anal. 30, 999-1012.

Meyer, S., Glaser, B., Quicker, P., 2011. Technical, economical and climate related aspects of biochar production technologies: a literature review. Environ. Sci. Technol. 45, 110930141845009. http://dx.doi.org/10.1021/es201792c.

Mohammadi, M.H., Vanclooster, M., 2014. Predicting the soil moisture retention curve, from soil particle size distribution and bulk density data using a packing density scaling factor. Hydrol. Earth Syst. Sci. 18, 4053-4063. http://dx.doi.org/10.5194/ hess-18-4053-2014.

Ngole-jeme, V.M., Ekosse, G.-I.E., 2015. A comparative analyses of granulometry, mineral composition and major and trace element concentrations in soils commonly ingested by humans. Int. J. Environ. Res. Public Health 12, 8933-8955. http://dx.doi.org/10. 3390/ijerph120808933.

Nguyen, M.N., Dultz, S., Tran, T.T.T., Bui, A.T.K., 2013. Effect of anions on dispersion of a kaolinitic soil clay: a combined study of dynamic light scattering and test tube experiments. Geoderma 209-210, 209-213. http://dx.doi.org/10.1016/j.geoderma. 2013.06.024.

Nguyen, M.N., Picardal, F., Dultz, S., Dam, T.T.N., Nguyen, A.V., Nguyen, K.M., 2017 Silicic acid as a dispersibility enhancer in a Fe-oxide-rich kaolinitic soil clay. Geoderma 286, 8-14. http://dx.doi.org/10.1016/j.geoderma.2016.10.029.

Noronha, V.T., Sousa, F.A., Souza Filho, A.G., Silva, C.A., Cunha, F.A., Koo, H., Fechine, P.B.A., Paula, A.J., 2017. Influence of surface silanization on the physicochemical stability of silver nanocoatings: a large length scale assessment. J. Phys. Chem. C 121, 11300-11311. http://dx.doi.org/10.1021/acs.jpcc.7b00706.

Oguntunde, P.G., Fosu, M., Ajayi, A.E., van de Giesen, N., 2004. Effects of charcoal production on maize yield, chemical properties and texture of soil. Biol. Fertil. Soils 39, 295-299. http://dx.doi.org/10.1007/s00374-003-0707-1.

Oliveira, N.C., Silva, J.H., Barros, O.A., Pinheiro, A.P., Santana, W., Saraiva, A.A.F., 
Ferreira, O.P., Freire, P.T.C., Paula, A.J., 2015. Large-field electron imaging and Xray elemental mapping unveil the morphology, structure, and fractal features of a cretaceous fossil at the centimeter scale. Anal. Chem. 87, 10088-10095. http://dx. doi.org/10.1021/acs.analchem.5b02815.

Oliveira, S.P., Lacerda, N.B., Blum, S.C., Escobar, M.E.O., Oliveira, T.S., 2015. Organic carbon and nitrogen stocks in soils of northeastern Brazil converted to irrigated agriculture. Land Degrad. Dev. 26, 9-21.

Pascaud, G., Soubrand, M., Lemee, L., Laduranty, J., El-Mufleh, A., Rabiet, M., Joussein, E., 2017. Molecular fingerprint of soil organic matter as an indicator of pedogenesis processes in technosols. J. Soils Sediments 17, 340-351. http://dx.doi.org/10.1007/ s11368-016-1523-1.

Paula, A.J., Stefani, D., Souza Filho, A.G., Kim, Y.A., Endo, M., Alves, O.L., Stefani, D., Souza, A.G., 2011. Surface chemistry in the process of coating mesoporous $\mathrm{SiO}_{2}$ onto carbon nanotubes driven by the formation of $\mathrm{Si}-\mathrm{O}-\mathrm{C}$ bonds. Chem. Eur. J. 17, 3228-3237. http://dx.doi.org/10.1002/chem.201002455.

Paz-Ferreiro, J., Gascó, G., Gutiérrez, B., Méndez, A., 2012. Soil biochemical activities and the geometric mean of enzyme activities after application of sewage sludge and sewage sludge biochar to soil. Biol. Fertil. Soils 48, 511-517. http://dx.doi.org/10. 1007/s00374-011-0644-3.

Paz-Ferreiro, J., Méndez, A., Tarquis, A.M., Cerdà, A., Gascó, G., 2014. Preface: environmental benefits of biochar. Solid Earth 5, 1301-1303.

Qian, J., Wang, Z.J., Shan, X.Q., Tu, Q., Wen, B., Chen, B., 1996. Evaluation of plant availability of soil trace metals by chemical fractionation and multiple regression analysis. Environ. Pollut. 91, 309-315. http://dx.doi.org/10.1016/0269-7491(95) 00066-6.

Raghothama, K.G., Karthikeyan, A.S., 2005. Phosphate acquisition. Plant Soil 274, 37-49.

van Reeuwijk, L.P., 2002. Procedures for soil analysis. In: Technical Paper, No 9 (Wageningen).

Ribeiro-Soares, J., Cançado, L.G., Falcão, N.P.S., Martins Ferreira, E.H., Achete, C.A., Jorio, A., 2013. The use of Raman spectroscopy to characterize the carbon materials found in Amazonian anthrosoils. J. Raman Spectrosc. 44, 283-289. http://dx.doi. org /10.1002/jrs.4191.

Rinnan, R., Rinnan, Å., 2007. Application of near infrared reflectance (NIR) and fluorescence spectroscopy to analysis of microbiological and chemical properties of arctic soil. Soil Biol. Biochem. 39, 1664-1673. http://dx.doi.org/10.1016/j.soilbio.2007. 01.022 .

Ros, T.G., van Dillen, A.J., Geus, J.W., Koningsberger, D.C., 2002. Surface oxidation of carbon nanofibres. Chem. Eur. J. 8, 1151-1162.

Roscoea, R., Buurmanb, P., 2003. Tillage effects on soil organic matter in density fractions of a cerrado oxisol. Soil Tillage Res. 70, 107-119.

Sato, S., Neves, E.G., Solomon, D., Liang, B., Lehmann, J., 2009. Biogenic calcium phosphate transformation in soils over millennial time scales. J. Soils Sediments 9 , 194-205. http://dx.doi.org/10.1007/s11368-009-0082-0.

Schachtman, D.P., Reid, R.J., Ayling, S.M., 1998. Phosphorus uptake by plants: from soil to cell. Plant Physiol. 116, 447-453.

Sohi, S.P., Krull, E., Lopez-Capel, E., Bol, R., 2010. Chapter 2 - a review of biochar and its use and function in soil. Adv. Agron. 105, 47-82.

Soil Survey Staff, 2014. Keys to Soil Taxonomy. (Washington, DC).

Sousa, F.A., Noronha, V.T., Machado, T.F., Silveira, J.V., Cunha, F.A., Fechine, P.B.A.,
Paula, A.J., 2017. Silver nanocoatings at large length scales: influence of the AgNPs morphology and capping agents on the coating chemical stability and antimicrobial effect. J. Braz. Chem. Soc. 28, 1639-1649.

Steiner, C., 2007. Soil charcoal amendments maintain soil fertility and establish a carbon sink-research and prospects. In: Liu, T.X. (Ed.), Soil Ecology and Research Developments. Nova Science Publishers, Hauppauge, pp. 1-6.

Taube, P.S., Hansel, F.A., dos S. Madureira, L.A., Teixeira, W.G., 2013. Organic geochemical evaluation of organic acids to assess anthropogenic soil deposits of Central Amazon, Brazil. Org. Geochem. 58, 96-106. http://dx.doi.org/10.1016/j. orggeochem.2013.02.004.

Udelhoven, T., Emmerling, C., Jarmer, T., 2003. Quantitative analysis of soil chemical properties with diffuse re ectance spectrometry and partial least-square regression: a feasibility study. Plant Soil 251, 319-329.

USEPA-United States Environmental Protection Agency, 1996. Method 3050B. In: Acid Digestion of Sediments, Sludges and Soils, (Washington, DC).

Valente, G.J.S.S., Costa, M.L., 2017. Fertility and desorption capacity of Anthrosols (Archaeological Dark Earth - ADE) in the Amazon: the role of the ceramic fragments (sherds). Appl. Clay Sci. 138, 131-138.

Villaverde, J., Van Beinum, W., Beulke, S., Brown, C.D., 2009. The kinetics of sorption by retarded diffusion into soil aggregate pores. Environ. Sci. Technol. 43, 8227-8232. http://dx.doi.org/10.1021/es9015052.

Vitousek, P.M., Sanford, R.L., 1986. Nutrient cycling in moist tropical forest. Annu. Rev. Ecol. Evol. Syst. 17, 137-167.

Walker, T.W., Syers, J.K., 1976. The fate of phosphorus during pedogenesis. Geoderma 15, 1-19.

Wang, L., Sheng, R., Yang, H., Wang, Q., Zhang, W., Hou, H., Wu, J., Wei, W., 2017. Stimulatory effect of exogenous nitrate on soil denitrifiers and denitrifying activities in submerged paddy soil. Geoderma 286, 64-72. http://dx.doi.org/10.1016/j. geoderma.2016.10.023.

Xinde, C., Xiaorong, W., Guiwen, Z., 2000. Assessment of the bioavailability of rare earth elements in soils by chemical fractionation and multiple regression analysis. Chemosphere 40, 23-28. http://dx.doi.org/10.1016/S0045-6535(99)00225-8.

Yang, F., Zhao, L., Gao, B., Xu, X., Cao, X., 2016. The interfacial behavior between biochar and soil minerals and its effect on biochar stability. Environ. Sci. Technol. 50, 2264-2271. http://dx.doi.org/10.1021/acs.est.5b03656.

Yin, Y., Wang, L., Liang, C., Xi, F., Pei, Z., Du, L., 2016. Soil aggregate stability and iron and aluminium oxide contents under different fertiliser treatments in a long-term solar greenhouse experiment. Pedosphere 26, 760-767. http://dx.doi.org/10.1016/ S1002-0160(15)60086-8.

Zhang, A., Cui, L., Pan, G., Li, L., Hussain, Q., Zhang, X., Zheng, J., Crowley, D., 2010. Effect of biochar amendment on yield and methane and nitrous oxide emissions from a rice paddy from Tai Lake plain, China. Agric. Ecosyst. Environ. 139, 469-475.

Zhang, A., Liu, Y., Pan, G., Hussain, Q., Li, L., Zheng, J., Zhang, X., 2012. Effect of biochar amendment on maize yield and greenhouse gas emissions from a soil organic carbon poor calcareous loamy soil from Central China Plain. Plant Soil 351, 263-275. http:// dx.doi.org/10.1007/s11104-011-0957-x.

van Zwieten, L., Kimber, S., Downie, A., Morris, S., Petty, S., Rust, J., Chan, K.Y., 2010. A glasshouse study on the interaction of low mineral ash biochar with nitrogen in a sandy soil. Aust. J. Soil Res. 48, 569-576. 